\title{
GRAPHITE-BEARING PERIDOTITES FROM THE KAAPVAAL CRATON: THEIR CARBON ISOTOPIC COMPOSITIONS AND IMPLICATIONS FOR PERIDOTITE THERMOBAROMETRY.
}

\author{
D.G. Pearson ${ }^{(1)}$; F.R. Boyd ${ }^{(2)}$; S.W. Field ${ }^{(3)}$; J.D. Pasteris ${ }^{(4)}$; S.E. Haggerty ${ }^{(5)}$ and P.H. Nixon $^{(6)}$.
}

(1) Dept. of Terrestrial Magnetism, Carnegie Institution of Washington, Washington D.C. 20015, U.S.A.; (2) Geophysical Laboratory, Carnegie Institution of Washington; (3) Dept. of Geology, Stockton State College, Pomona, NJ 08240, U.S.A.; (4) Dept. of Earth \& Planetary Sciences, Washington University, St. Louis, MO 63130; (5) Dept. of Geology \& Geography, University of Massachusets, Amherst, MA 01003, U.S.A.; (6) Dept. of Earth Sciences, Univ. of Leeds, Leeds LS29JT, U.K.

The graphite-bearing ultramafic xenoliths studied in this investigation are predominantly coarse, low-temperature peridotites derived from the Kaapvaal lithosphere. Two specimens, however, are exsolved megacrysts, probably derived from low-temperature pyroxenites. The peridotites include garnet harzburgites exhibiting variable depletion in $\mathrm{Ca}$, garnet lherzolites, a spinel-facies peridotite and pargasite (amphibole) peridotites. These xenoliths have come from kimberlites erupted along the southern margin of the Kaapvaal craton (Kimberley, Jagersfontein and northern Lesotho) as well as the Premier pipe in the central part of the craton. To our knowledge, no graphitebearing peridotites have been found in xenolith suites from off-craton kimberlites in East-Griqualand and Namibia.

Graphite most commonly occurs as dispersed, subhedral to euhedral flakes and multicrystalline stacks of flakes with a grain size ranging up to $3 \mathrm{~mm}$. In many specimens the graphite is interstitial, but in some the graphite flakes are enclosed in primary grains, particularly garnet and enstatite. Multiple flakes of graphite in a single xenolith are the rule, some xenoliths contain as many as several tens or more. Aggregates of graphite crystals have a vein-like planar distribution in two specimens from Jagersfontein. In pargasite-bearing garnet peridotite PHN5633, the flakes of graphite are concentrated on a flat face of the xenolith, suggestive of an origin on a vein wall. In garnet lherzolite JAG 500 the graphite is concentrated in two diffuse bands, one coincident with a zone of garnet and diopside. The second graphite band is parallel but transects coarse olivine and enstatite. An orthopyroxenite xenolith from Premier (FRB1399) contains polycrystalline blebs of graphite as well as graphite inclusions in enstatite, together forming 10-20\% of the xenolith.

The graphites from the peridotites give Raman spectra comparable to those from well ordered, highly crystalline graphite from granulitefacies terranes (Pasteris \& Wopenka, 1991) with well defined first- and second-order peaks, at or close to the the normal peak positions. The spectra indicate that the graphite is of high-temperature origin and distinct from the fine-grained graphite found in serpetinised kimberlitic olivine (Pasteris, 1988). However, numerous graphites from an exsolved megacryst, JX-23, show deviation from the above spectra, with downshifting of the first- and second-order peaks that is not presently understood.

Estimates of equilibration temperature and pressure for the graphite peridotites range widely from those characteristic of the shallow mantle to those corresponding to the diamond-graphite transition. A graphite-bearing spinel-facies peridotite from letseng (PHN4258) has equilibrated near the top of the mantle. Greater temperatures and depths calculated for the garnet-bearing peridotites, using a variety of thermbarometer combinations, are consistently less than those calculated for diamond-bearing peridotites (Fig. 1). This consistent relationship is evidence that the graphite and diamond in these rocks have crystallised within their respective stability fields. A point for a graphite peridotite overlaps a point for a diamond peridotite in only one plot (Fig. 1D). This may be interpreted as either an exception to the consistency or a minor failure of the thermobarometer in application to natural samples.

The transition in temperature and depth from graphite to diamond peridotites that is illustrated by the plots in Fig. 1 approximates the 
graphite-diamond equilibrium boundary determined by experiment. This relationship represents a success for peridotite thermobarometry and it appears that the calculation used for Fig. 1A is the most successful. A lesser number of points appear in plots for which temperature was calculated from the pyroxene solvus (Fig. $1 \mathrm{~A} \& \mathrm{C}$ ) because many of the graphite peridotites lack diopside.

Graphites from the peridotite xenoliths show a range in $\delta^{13} \mathrm{C}$ from $-3.8 \%$ to $-12.3 \%$ (Table 1 ) with a mode between -5 and $-7 \%$ (Fig. 2). The range encompasses the $-10.0 \%$ value for graphite from a Kimberley garnet harzburgite found by Schulze and Valley (submitted). Graphite from the two exsolved megacrysts fall within this range (Table 1). Graphite has up to $1.6 \%$ variation between individual flakes in the amphibole-bearing specimen PHN5633 and a 1.4\% variation in the the "vein" graphite from JAG500. This variation could be due to progressive carbon isotope fractionation in a gas phase that deposited the graphite. The occurrence of multiple flakes of graphite in vein-like form in several Jagersfontein peridotites suggests a metasomatic origin (Field and Haggerty, 1990). All the graphites from peridotites fall within the range of $\delta^{13} \mathrm{C}$ values of peridotite suite diamonds and are also within a few $\%$ of the range of carbon extracted from MORB glasses. This indicates that the graphite in the lithospheric peridotites crystallised from a similar reservoir to peridotite suite diamonds. The isotopic similarity between this reservoir and carbon from the asthenospheric mantle, as characterised by MORB glasses, is consistent with the crystallisation of both diamonds and graphite in the lithospheric mantle from asthenosphere-derived fluids.

Table 1. Carbon Isotope Composition of Graphite from Kaapvaal Peridotites

\begin{tabular}{|c|c|c|c|}
\hline Sample & Locality & Lithology_ & $\delta^{13} \mathrm{C} \%$ \\
\hline \multicolumn{4}{|c|}{ PERIDOTITES } \\
\hline E-8 & Thaba Putsoa & \multirow{4}{*}{$\begin{array}{l}\text { Gt harzburgite } \\
\text { Harzgurgite } \\
\text { Gt lherzolite } \\
\text { Low-Ca } \\
\text { Gt harzburgite }\end{array}$} & -9.8 \\
\hline PHN 1555a & Mothae & & -12.3 \\
\hline PHN 1569 & Thaba Putsoa & & 6.7 \\
\hline PHN 2492 & Kao No.2 & & -5.8 \\
\hline PHN4258 & Letseng-la-Terai & \multirow{4}{*}{$\begin{array}{l}\text { Sp.harzburgite } \\
\text { Pargasite } \\
\text { bearing } \\
\text { Gt harzburgite }\end{array}$} & -7.1 \\
\hline PHN 5633 (a) & Jagersfontein & & -6.9 \\
\hline PHN 5633 (c) & 4 & & -6.3 \\
\hline PHN 5633 (d) & $"$ & & -7.9 \\
\hline \multirow{2}{*}{$\begin{array}{l}\text { JAG } 84-500 \text { (a) } \\
\text { JAG } 84-500 \text { (b) }\end{array}$} & \multirow[t]{2}{*}{ Jagersfontein } & \multirow{4}{*}{$\begin{array}{l}\text { Graphite } \\
\text { associated with } \\
\text { Gt-Cpx veins } \\
\text { in Gt } \\
\text { harzburgite }\end{array}$} & $\begin{array}{r}-5.4 \\
-4.8\end{array}$ \\
\hline & & & -4.8 \\
\hline JAG 84-500 (A) & \multirow{2}{*}{$\underset{\|}{\text { Jagersfontein }}$} & & -4.0 \\
\hline JAG 84-500 (B) & & & -5.2 \\
\hline \multirow{3}{*}{$\begin{array}{l}\text { JAG } 89-5 \\
\text { FRB } 888\end{array}$} & Jagersfontein & \multirow{3}{*}{$\begin{array}{l}\text { Gt harzburgite } \\
\text { Gt harzburgite } \\
\text { RYSTS }\end{array}$} & -3.8 \\
\hline & Bulfontein & & -5.0 \\
\hline & EXSOLV & & \\
\hline \multirow{2}{*}{$\begin{array}{l}\text { JX-23 } \\
\text { JAG 89-10 }\end{array}$} & Jagersfontein & \multirow[b]{2}{*}{ Opx ex Cpx ,Gt } & -6.8 \\
\hline & Jagersfontein & & -7.2 \\
\hline
\end{tabular}

References

Brey, G.P, Kohler, T.P., and Nickel, K.G. (1990) Geothermobarometry in natural four phase lherzolites, part I: Experimental results from $10-60 \mathrm{~kb}$. Journal of Petrology, 31,1313-1352.

Deines, P, Harris, J.W. and Gurney, J.J. (1987) Carbon isotopic composition, nitrogen content and inclusion composition of diamonds from the Roberts Victor kimberlite, South Africa. Geochimica Cosmochimica Acta, 51,1227-1243.

Field, S.W. and Haggerty, S.E. (1990) Graphitic xenoliths from the Jagersfontein kimberlite, South Africa: Evidence for dominantly anhydrous melting and carbon deposition. EOS, 71,658.

Kropotova and Fedorenko, B.V. (1970) Carbon isotopic composition of diamond and graphite from eclogite. Geokhimiya, 10, 1279 (in Russian). Pasteris, J.D. (1988) Secondary graphitisation in mantle-derived rocks. Geology, 16, 804-807.

Pasteris, J.D. and Wopenka, B. (1991) Raman spectra of "graphite" as indicators of degree of metamorphism. Canadian Mineralogist (in press) 
Pearson, D.G., Boyd, F.R. and N1xon, P.H. (1990) Graphite-bearing mantle xenoliths from the Kaapvaal craton: Implications for graphite and diamond genesis. Carnegie Inst. Yearbook 1989-1990, 11-19.

Schulze, D.J.and Valley, J.W. (submitted) Carbon 1sotopic composition and equilibration conditions of graphite-bearing eclogite and garnet peridotite xenoliths from kimberlite: Anomalously light carbon subducted into the shallow lithospheric mantle. American Mineralogist.

Sobolev, N.V., Gailmov, E.M., Ivanovskaya, I.N. and Yeflmova, E.S. (1979) The carbon isotope compositions of diamonds containing crystallographic 1nclusions. Doklady Academ11 Nauk SSSR, 249, 1217-1220.

Taylor, B.E. (1986) Magmatic volatiles: Isotopic variations of $\mathrm{C}, \mathrm{H}$ and S, In J.W. Valley, H.P. Taylor Jr and J.R. O'Nelll, Eds., Stable Isotopes in High Temperature Geological Processes, p185-219, Min.Soc.Am.
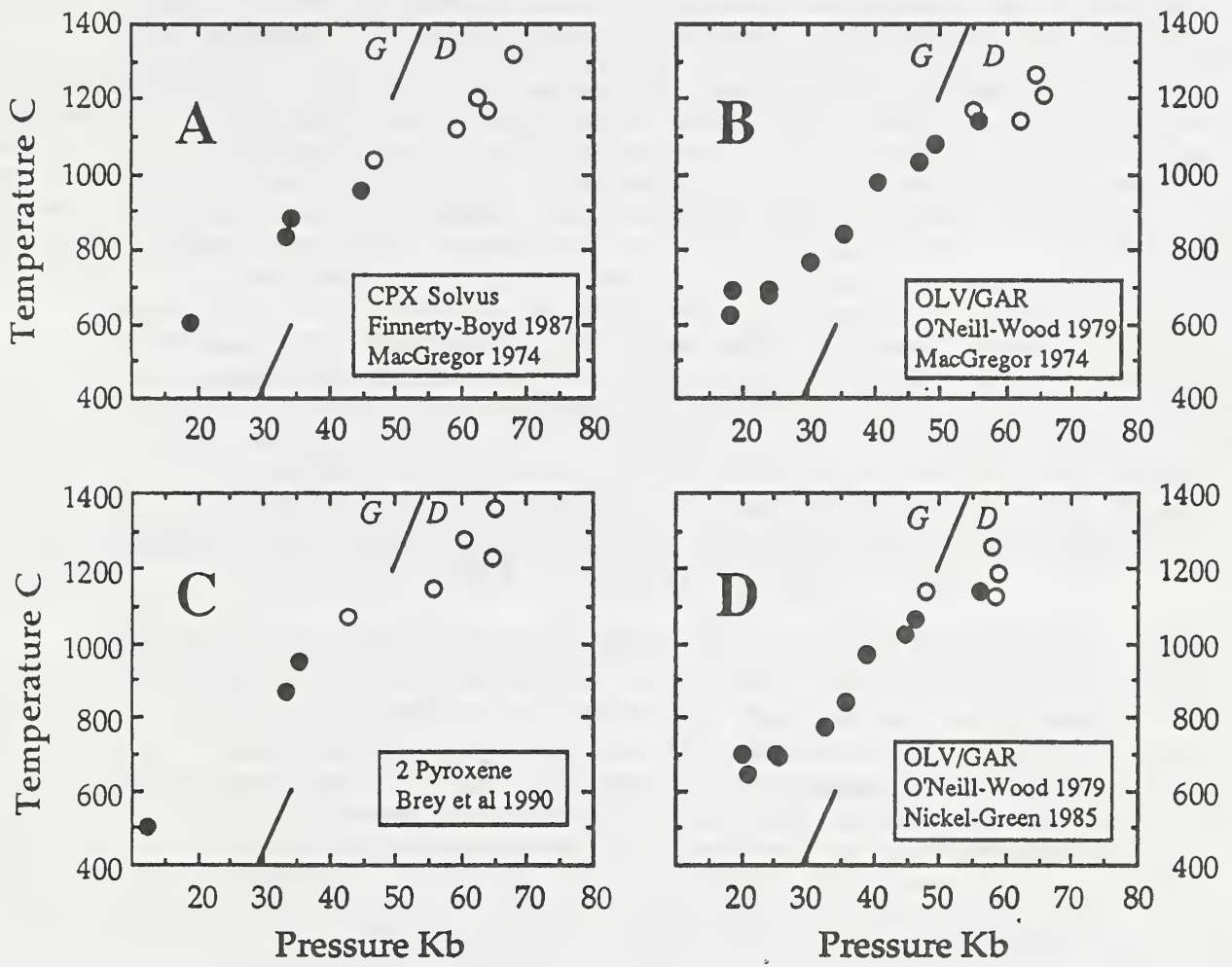

Fig.1: Temperature and pressure of equilibration for graphite-peridotites (solid circles) and diamond-bearing peridotites (solid circles) estimated with a variety of thermobarometers. Specimens include lherzolites, harzburgites and amphibole-bearing peridotites.[A]: T by the Finnerty \& Boyd, 1987, pyroxene solvus thermometer (FB86), P by the MacGregor, 1974, (MC74) barometer.[B]: T by $\mathrm{Fe} / \mathrm{Mg}$ olivine-garnet, O'Neill \& Wood, 1979, P by MC74 as in A.[C]: T (2-pyroxene solvus) \& P (BKN) Brey et al, 1990.[D]: T by olivine-garnet as in B, $P$ by Al in OPX, Nickel \& Green,1985 (NG85). For references see Pearson et al (1990).

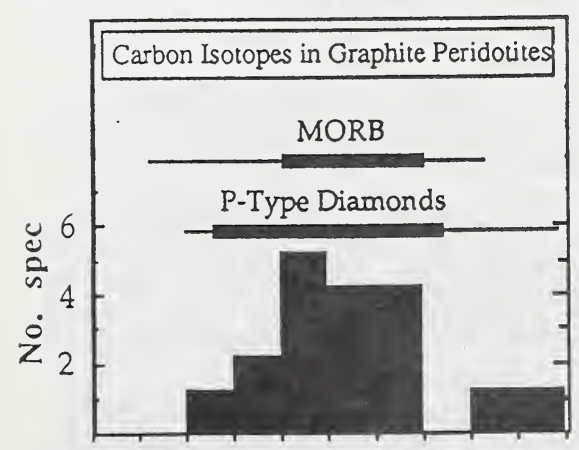

Fig. 2: Histogram of carbon isotope data from graphite peridotites (this report \& Kropotova \& Fedorenko, 1970) compared to P-Type diamonds (Sobelov et al,1979; Deines et al,1987) and carbon in MORB glasses (Taylor, 1986). Thick bars represent $90 \%$ of analyses.

$\cdot 1 \cdot 2 \cdot 3 \cdot 4 \cdot 5 \cdot 6 \cdot 7 \cdot 8 \cdot 9 \cdot 12$

$\delta^{13} \mathrm{C} \%$ 